\title{
Bioedusiana
}

http://jurnal.unsil.ac.id/index.php/bioed/index

DOI: https://doi.org/10.34289/292823

\section{PENERAPAN MODEL PEMBELAJARAN KOOPERATIF TIPE JIGSAW DALAM MENUMBUHKAN KETERAMPILAN KOMUNIKASI DAN HASIL BELAJAR KOGNITIF PESERTA DIDIK KELAS X SMA MUHAMMADIYAH 2 BANDAR LAMPUNG \\ The Application of Cooperative Learning Models Jigsaw Type in Improving Students' Communication Skill and Students' Cognitive Learning at Tenth Grade of SMA Muhammadiyah 2 Bandar Lampung}

\author{
Khoiriya Ulfa $^{1)}$, Tri Jalmo ${ }^{1)}$, Arwin Surbakti ${ }^{1)}$ \\ ${ }^{1)}$ Program Studi Pendidikan Biologi, Universitas Lampung, J1. Prof. Dr. Soemantri Brojonegoro No.1 \\ Bandar Lampung, 35145 \\ Email korespondensi: khoiriyaulfa44@gmail.com
}

\section{Info Artikel}

Sejarah Artikel:

Diterima 10 Oktober

2019

Disetujui 7 November

2019

Dipublikasikan 1

Desember 2019

\section{Keywords:}

Pembelajaran kooperatif tipe

Jigsaw, Keterampilan

komunikasi, Hasil belajar kognitif.

\begin{abstract}
Abstrak
Penelitian ini bertujuan untuk mengetahui efektivitas model pembelajaran kooperatif tipe Jigsaw dalam menumbuhkan keterampilan komunikasi lisan dan meningkatkan hasil belajar kognitif peserta didik kelas X SMA Muhammadiyah 2 Bandar Lampung. Penelitian ini menggunakan desain One Group Pretest-Posttest Desain. Populasi penelitian adalah semua kelas X SMA Muhammadiyah 2 Bandar Lampung. Sampel penelitian ini yaitu kelas X Mia 1 SMA Muhammadiyah 2 Bandar Lampung yang berjumlah 35 siswa/i. Pengambilan sampel dalam penelitian ini menggunakan teknik purposive sampling. Data diperoleh dari angket self assessment, angket peer assessment, dan lembar observasi, sedangkan data hasil belajar kognitif peserta didik diperoleh dari 20 soal pilihan ganda. Data tersebut dianalisis menggunakan analisis deskriptif. Hasil penelitian menunjukkan bahwa model pembelajaran kooperatif tipe Jigsaw efektif dalam menumbuhkan keterampilan komunikasi lisan diperoleh kategori cukup dengan persentase lebih dari $75 \%$, serta hasil belajar kognitif diperoleh kategori sedang dengan nilai N-gain 0,56. Kesimpulannya, model pembelajaran kooperatif tipe Jigsaw dapat menumbuhkan keterampilan komunikasi lisan serta meningkatkan hasil belajar kognitif peserta didik.
\end{abstract}

\section{Abstract}

The aims of this research were to find out the effectiveness of cooperative learning models type jigsaw in improving students' verbal communication skills and improving students' cognitive learning outcomes at the tenth grade of SMA Muhammadiyah 2 Bandar Lampung. One Group Pretest-Posttest was used as a design of this research. The population of this research was the tent grade of SMA Muhammadiyah 2 Bandar Lampung. X Mia 1 was choosed as a sample, which consisted of 35 students. This research used purposive sampling technique. The data was obtained from the self assessment questionnaire, peer assessment questionnaire, observation sheet, and the cognitive learning outcomes data of students was multiple choices test in 20 items. The data was analyzed by using descriptive analysis. The results showed that cooperative learning models of jigsaw type was effective in improving students' communication skills in enough category with percentage more than $75 \%$, and cognitive learning outcomes obtained in the moderate category with $N$-gain value of 0.56 . In conclusion, cooperative learning models of jigsaw type can improve students' verbal communication skills and can improve students' cognitive learning outcomes.

(C) 2019 Universitas Siliwangi ISSN: 2684-7604 (online)

ISSN: $2477-5193$ (print)

\footnotetext{
Jurusan Pendidikan Biologi FKIP Universitas Siliwangi

Gedung Perkantoran FKIP Lt. 3

Jalan Siliwangi No. 24 Kota Tasikmalaya 46115

HP. 08112344989 (a.n. Rinaldi Rizal Putra, M.Sc.)

E-mail: bioedusiana@unsil.ac.id
}

Alamat korespondensi: 


\section{PENDAHULUAN}

Keterampilan komunikasi adalah salah satu kompetensi penting bagi warga global abad ke-21 karena keterampilan komunikasi adalah salah satu pondasi penting yang menjadi dasar dalam pembelajaran sains (Chung, 2014: 10). USbased Partnership for 21st Century Skills (P21), mengidentifikasi kompetensi yang diperlukan di abad ke-21 yaitu "The 4Cs"- communication, collaboration, critical thinking, dan creativity. Kompetensi-kompetensi tersebut penting diajarkan pada peserta didik dalam konteks bidang studi inti dan tema abad ke-21.

Keterampilan komunikasi juga merupakan salah satu hal mendasar dalam kurikulum banyak negara (Kulgemeyer, 2013: 1), Misalnya Australia, kerangka kurikulum untuk pendidikan taman kanak-kanak sampai kelas 12 di Australia barat menekankan perlunya memberi siswa kesempatan untuk berkomunikasi dalam berbagai komunikasi lokal, nasional dan global (Council, 1998), pada kurikulum 2013 di Indonesia menuntut pelaksanaan pembelajaran dengan pendekatan ilmiah. Melalui pendekatan ilmiah peserta didik diperkenalkan dengan kemampuan untuk mengamati, menanya, mencoba, mengasosiasi dan mengkomunikasikan.

Namun kenyataannya kemampuan sains ilmiah peserta didik di Indonesia masih tergolong rendah yang berpengaruh terhadap hasil belajar kognitif peserta didik. Hal ini didasari dari menurunnya nilai UN di Indonesia 3 tahun terakhir terutama pada mata pelajaran IPA ratarata nilai IPA pada sekolah negeri dan swasta tahun 2016 rata-rata 65,05, sedangkan pada tahun 2017 rata-rata nilai IPA 55,51, dan tahun 2018 rata-rata nilai IPA 52,96. Di Lampung sendiri nilai UN peserta didik pada tahun 2018 rata-ratanya hanya 47,98 (Kemendikbud,2008). Selain itu seperti hasil survei yang telah dilakukan di beberapa sekolah di Bandar Lampung, diperoleh informasi bahwa 90\% guru SMA di Bandar Lampung sudah menciptakan kondisi yang memungkinkan peserta didik untuk memberdayakan keterampilan komunikasi. Sebagian guru paham bahwa keterampilan komunikasi merupakan keterampilan yang harus dikembangkan dalam kurikulum 2013, akan tetapi keterampilan komunikasi peserta didik masih tergolong rendah karena selama ini guru menggunakan model pembelajaran ceramah yang kurang dalam melatih keterampilan komunikasi peserta didik. Guru juga belum pernah mengukur keterampilan komunikasi peserta didik.

Solusi dalam melatih keterampilan komunikasi peserta didik yaitu dengan menggunakan model pembelajaran kooperatif tipe Jigsaw karena dalam model pembelajaran Jigsaw siswa akan dilatih berkomunikasi dalam satu kelompok yang bertanggung jawab atas penguasaan bagian materi belajar dan mampu mengajarkan materi tersebut kepada anggota lain dalam kelompoknya (Arends R.I.,1997).

Tujuan penelitian ini yaitu untuk (1) mengetahui efektivitas model pembelajaran kooperatif tipe Jigsaw dalam menumbuhkan keterampilan komunikasi lisan peserta didik kelas X SMA Muhammadiyah 2 Bandar Lampung pada materi pokok ekosistem, (2) mengetahui efektivitas model pembelajaran kooperatif tipe Jigsaw dalam meningkatkan hasil belajar kognitif peserta didik kelas X SMA Muhammadiyah 2 Bandar Lampung pada materi pokok ekosistem.

\section{METODE}

Penelitian ini telah dilaksanakan pada bulan Mei 2019 di semester genap tahun pelajaran 2018-2019 di SMA Muhammadiyah 2 Bandar Lampung yang beralamat di Jalan Zainal Abidin Pagar Alam, Labuhan Ratu, Kedaton, Kota Bandar Lampung.

Populasi dalam penelitian ini adalah seluruh peserta didik kelas X SMA Muhammadiyah 2 Bandar Lampung tahun pelajaran 2018-2019. Pengambilan sampel dilakukan dengan menggunakan teknik purposive sampling (Sugiyono, 2016: 85). Sampling tersebut ialah peserta didik kelas X Mia 1 dengan jumlah 35 siswa/i sebagai kelas eksperimen.

Desain yang digunakan pada penelitian ini adalah desain One Group Pretest-Postest Desain. Pada desain ini juga hanya melibatkan satu kelompok tetapi observasi dilakukan dua kali, di awal dan akhir perlakuan. One group pretest-posttest design pada dasarnya melakukan kegiatan memberikan tes awal (pretest) sebelum diberikan perlakuan, setelah diberikan perlakuan kemudian memberikan tes akhir (posttest). Setelah melihat pengertian tersebut dapat ditarik simpulan bahwa hasil perlakuan dapat diketahui lebih akurat 
karena dapat membandingkan sesudah dengan keadaan sebelum diberikan perlakuan (Arikunto, 2010: 124).

Tabel 1. Desain penelitian One Group PretestPostest Desain.

\begin{tabular}{|l|l|l|}
\hline Pretest & Treatment & Posttest \\
\hline $\mathrm{O}_{1}$ & $\mathrm{X}$ & $\mathrm{O}_{2}$ \\
\hline
\end{tabular}

Sumber : (Arikunto, 2010: 124)

Keterangan :

$\mathrm{O}_{1:}$ Tes awal (pretest) sebelum diberi perlakuan

$\mathrm{O}_{2:}$ Tes akhir (posttest) setelah diberi perlakuan
X: Perlakuan terhadap kelompok eksperimen yaitu dengan menerapkan model pembelajaran tipe Jigsaw.

Adapun jenis data dan teknik pengumpulan data pada penelitian ini berupa data kuantitatif dan kualitatif. Data kuantitatif berupa hasil belajar peserta didik yang didapatkan dari pretestposttest, sedangkan data kualitatif berupa hasil pengukuran dari self assessment, peer assessment, dan lembar observasi. Data ini dapat digambarkan dalam Tabel 2 berikut ini:

Tabel 2. Jenis data dan teknik pengumpulan data

\begin{tabular}{|c|c|c|c|}
\hline No & Jenis Data & Teknik pengambilan data & Waktu pengambilan data \\
\hline 1 & $\begin{array}{c}\text { Kuantitatif } \\
\text { (Hasil belajar kognitif) }\end{array}$ & $\begin{array}{c}\text { Tes } \\
\text { (Instrumen Terlampir) }\end{array}$ & $\begin{array}{l}\text { Pretest-Posttes (sebelum dan sesudah } \\
\text { pembelajaran) }\end{array}$ \\
\hline 2 & $\begin{array}{c}\text { Kualitatif (Model } \\
\text { pembelajaran kooperatif } \\
\text { tipe Jigsaw }\end{array}$ & $\begin{array}{c}\text { Observasi keterlaksanaan sintaks Jigsaw (Instrumen } \\
\text { Terlampir) }\end{array}$ & Ketika proses pembelajaran \\
\hline \multirow{5}{*}{3} & \multirow{5}{*}{$\begin{array}{l}\text { Kualitatif (Keterampilan } \\
\text { komunikasi) }\end{array}$} & Self assessmen (Instrumen Terlampir) & $\begin{array}{l}\text { Sebelum dan sesudah } \\
\text { pembelajaran }\end{array}$ \\
\hline & & Peer assessment (Instrumen Terlampir) & Sesudah pembelajaran \\
\hline & & LKPD (Instrumen Terlampir) & Ketika proses pembelajaran \\
\hline & & Observasi keterampilan komunikasi (Instrumen terlampir) & Ketika proses pembelajaran \\
\hline & & Hasil rekaman & Ketika proses pembelajaran \\
\hline
\end{tabular}

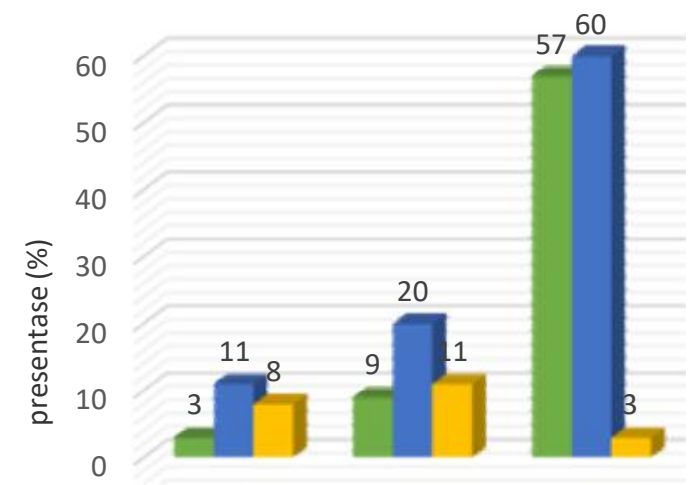

Gambar 1. Diagram Perubahan Keterampilan Komunikasi Lisan (n=35)

Teknik analisis data pada penelitian ini menggunakan deskriptif kualitatif. Teknik analisis data penelitian deskriptif kuantitatif menggambarkan data untuk memperoleh bentuk nyata dari responden, sehingga lebih mudah dimengerti. Data yang didapatkan berupa angka, maka cara mendeskripsikan data tersebut dapat dilakukan dengan menggunakan statistik deskriptif. Tujuan dilakukan analisis deskriptif dengan menggunakan teknik statistik adalah untuk meringkas data agar menjadi lebih mudah dilihat dan dimengerti.

\section{HASIL DAN PEMBAHASAN}

Hasil analisis data penelitian menunjukkan bahwa penggunaan model pembelajaran kooperatif tipe Jigsaw mampu meningkatkan keterampilan berkomunikasi secara lisan.

Berdasarkan diagram pada Gambar 1 tersebut yang diambil dari self assessment menunjukkan bahwa jumlah siswa yang sangat tinggi meningkat namun terjadi pengurangan pada kategori yang sangat rendah, hal ini dapat terlihat dari data perubahan antara sebelum dan sesudah yang menunjukkan bahwa sebesar $8 \%$ 
pada kategori sangat tinggi, 11\% pada kategori tinggi, 3\% pada kategori cukup, pada kategori rendah sebesar $-19 \%$ dan $-3 \%$ pada kategori sangat rendah. Hal tersebut terjadi karena peserta didik sudah banyak yang mengalami peningkatan setelah berdiskusi.

Pada Gambar 2 menunjukkan hasil bahwa lebih dari $75 \%$ peserta didik memiliki kriteria keterampilan komunikasi lisan dengan kategori "cukup" dilihat dari persentase hasil observasi sebesar 97\% peserta didik sudah mempunyai kemampuan komunikasi tertulis yang cukup. Selain itu, dapat dilihat pada Tabel 3 berdasarkan penilaian per indikator keterampilan komunikasi tertulis peserta didik yang diambil dari penilaian self assessment, peer assessment dan observasi diperoleh rata-rata persentase sebesar $73 \%$ dengan kategori cukup.

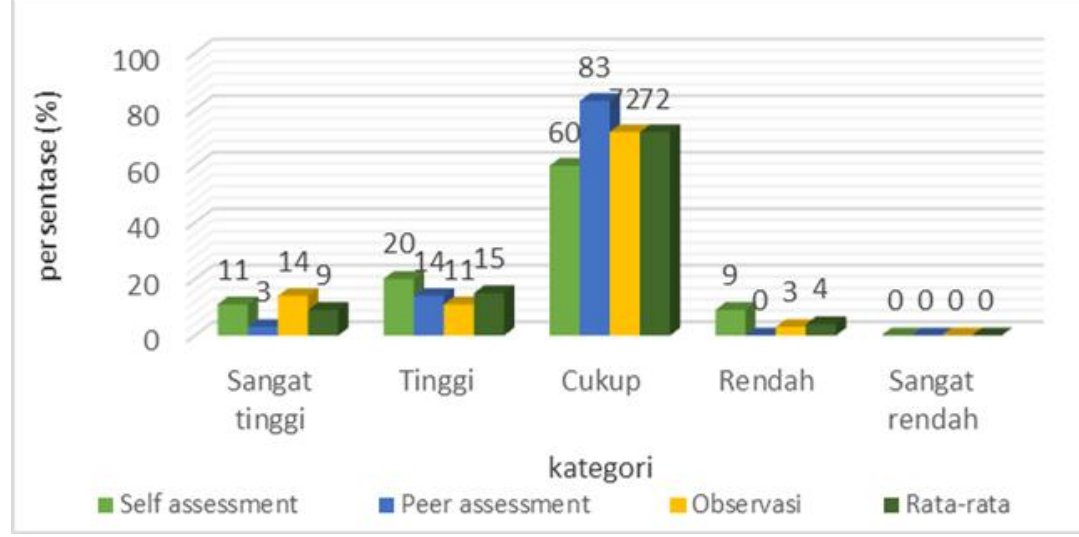

Gambar 2. Diagram Keterampilan komunikasi lisan $n=35$

Tabel 3. persentase indikator keterampilan komunikasi lisan

\begin{tabular}{|c|c|c|c|c|c|}
\hline \multirow[t]{2}{*}{ No. } & \multirow[t]{2}{*}{ Aspek dan Indikator Penilaian } & \multicolumn{3}{|c|}{$\begin{array}{c}\text { Persentase per Indikator } \\
\text { Penilaian }\end{array}$} & \multirow[t]{2}{*}{$\mathbf{X}$} \\
\hline & & SA & PA & $\mathbf{O}$ & \\
\hline 1. & Penyampaian informasi secara detail & $\begin{array}{c}76 \% \\
(\mathrm{~T})\end{array}$ & $\begin{array}{l}75 \% \\
(\mathrm{C})\end{array}$ & $\begin{array}{l}78 \% \\
(\mathrm{~T})\end{array}$ & $\begin{array}{l}76 \% \\
(\mathrm{~T})\end{array}$ \\
\hline 2. & Memberikan pertanyaan saat diskusi & $\begin{array}{c}74 \% \\
(\mathrm{C})\end{array}$ & $\begin{array}{c}62 \% \\
(\mathrm{C})\end{array}$ & $\begin{array}{c}70 \% \\
(\mathrm{C})\end{array}$ & $\begin{array}{c}69 \% \\
\text { (C) }\end{array}$ \\
\hline 3. & Kontak mata langsung & $\begin{array}{c}76 \% \\
(\mathrm{~T})\end{array}$ & $\begin{array}{c}70 \% \\
(\mathrm{C})\end{array}$ & $\begin{array}{c}71 \% \\
(\mathrm{C})\end{array}$ & $\begin{array}{c}72 \% \\
\text { (C) }\end{array}$ \\
\hline 4. & Menjawab pertanyaan audien & $\begin{array}{l}72 \% \\
(\mathrm{C})\end{array}$ & $\begin{array}{c}64 \% \\
\text { (C) }\end{array}$ & $\begin{array}{c}68 \% \\
(\mathrm{C})\end{array}$ & $\begin{array}{c}68 \% \\
\text { (C) }\end{array}$ \\
\hline 5. & Intonasi jelas & $\begin{array}{c}71 \% \\
(\mathrm{C})\end{array}$ & $\begin{array}{c}71 \% \\
(\mathrm{C})\end{array}$ & $\begin{array}{c}74 \% \\
(\mathrm{C})\end{array}$ & $\begin{array}{c}72 \% \\
\text { (C) }\end{array}$ \\
\hline 6. & Penggunaan contoh saat menjelaskan & $\begin{array}{l}74 \% \\
(\mathrm{C})\end{array}$ & $\begin{array}{l}75 \% \\
(\mathrm{C})\end{array}$ & $\begin{array}{l}76 \% \\
(\mathrm{~T})\end{array}$ & $\begin{array}{l}75 \% \\
(\mathrm{C})\end{array}$ \\
\hline 7. & Penggunaan grafik/gambar saat menjelaskan & $\begin{array}{l}70 \% \\
(\mathrm{C})\end{array}$ & $\begin{array}{l}72 \% \\
(\mathrm{C})\end{array}$ & $\begin{array}{l}70 \% \\
(\mathrm{C})\end{array}$ & $\begin{array}{l}71 \% \\
(\mathrm{C})\end{array}$ \\
\hline 8. & Penghubungan grafik/gambar saat menjelaskan & $\begin{array}{l}69 \% \\
(\mathrm{C})\end{array}$ & $\begin{array}{l}74 \% \\
(\mathrm{C})\end{array}$ & $\begin{array}{l}70 \% \\
(\mathrm{C})\end{array}$ & $\begin{array}{l}71 \% \\
(\mathrm{C})\end{array}$ \\
\hline 9. & Menggunakan tata bahasa yang mudah dimengerti & $\begin{array}{l}78 \% \\
(\mathrm{~T})\end{array}$ & $\begin{array}{l}80 \% \\
(\mathrm{~T})\end{array}$ & $\begin{array}{l}78 \% \\
(\mathrm{~T})\end{array}$ & $\begin{array}{l}79 \% \\
(\mathrm{~T})\end{array}$ \\
\hline 10. & Bahasa yang digunakan ringkas & $\begin{array}{l}77 \% \\
(\mathrm{~T})\end{array}$ & $\begin{array}{l}73 \% \\
(\mathrm{C})\end{array}$ & $\begin{array}{l}77 \% \\
(\mathrm{~T})\end{array}$ & $\begin{array}{l}76 \% \\
(\mathrm{~T})\end{array}$ \\
\hline & Rata-rata & $\begin{array}{l}74 \% \\
(\mathrm{C})\end{array}$ & $\begin{array}{l}72 \% \\
(\mathrm{C})\end{array}$ & $\begin{array}{l}73 \% \\
(\mathrm{C})\end{array}$ & $\begin{array}{l}73 \% \\
(\mathrm{C})\end{array}$ \\
\hline
\end{tabular}

Keterangan: $\mathrm{SA}=$ Self assessment, $\mathrm{PA}=$ Peer assessment, $\mathrm{O}=$ Observasi, $\mathrm{X}=$ Rata-rata. 
Peningkatan hasil belajar kognitif peserta didik dapat dilihat dari selisih antara pretest dengan posttest. Data $N$-gain hasil belajar kognitif peserta didik dapat dilihat pada Tabel 4 berikut.

Data di atas menunjukkan bahwa hasil belajar peserta didik kelas X Mia 1 pada materi ekosistem diperoleh data yaitu nilai posttest lebih besar dibandingkan dengan nilai pretest yang menunjukkan bahwa terjadi peningkatan dengan skor rata-rata nilai pretest sebesar 48,29, untuk rata-rata nilai postest sebesar $76,86, \mathrm{~N}$-gain sebesar 0,56 dengan kategori sedang. Rincian frekuensi ngain hasil belajar kognitif peserta didik terdapat pada Tabel 5 berikut.

Tabel 4. Nilai rata-rata pretest, posttest, gain, dan $n$-gain hasil belajar kognitif peserta didik

\begin{tabular}{|l|l|l|l|l|}
\hline \multirow{2}{*}{$\mathrm{N}$} & $\mathrm{X} \pm \mathrm{Sd}$ & \multirow{2}{|c|}{ Kategori } \\
\cline { 2 - 4 } & Pretest & Postest & N-Gain & \\
\hline 35 & $48,29 \pm 12,00$ & $76,86 \pm 10,28$ & $0,56 \pm 0,164$ & Sedang \\
\hline
\end{tabular}

Tabel 5. Frekuensi N-gain hasil belajar kognitif peserta didik

\begin{tabular}{|l|l|l|}
\hline Rentang Nilai & Kriteria & Frekuensi N-gain \\
\hline$N$-gain $>0,7$ & Tinggi & 10 \\
\hline $0,3 \leq N$-gain $\leq 0,7$ & Sedang & 22 \\
\hline$N$-gain 0,3 & Rendah & 3 \\
\hline
\end{tabular}



Gambar 3. N-gain hasil belajar kognitif

Peningkatan hasil belajar kognitif peserta didik dapat dilihat dari selisih antara hasil tes sebelum diberi perlakuan (pretest) dan hasil tes setelah diberi perlakuan (posttest). Data $N$-gain hasil belajar kognitif peserta didik dapat dilihat pada grafik berikut:

Berdasarkan data pada grafik N-gain hasil belajar kognitif di atas menyatakan bahwa, peserta didik yang memiliki nilai persentase $N$ gain tinggi sebesar 29\%, persentase $\mathrm{N}$-gain frekuensi sedang sebesar $63 \%$ dan persentase frekuensi $\mathrm{N}$-gain rendah sebesar $8 \%$. Frekuensi nilai $N$-gain tinggi dapat ditentukan apabila $N$-gain $>0,7$, sedangkan pada frekuensi sedang nilainya dari $0,3 \leq N$-gain $\leq 0,7$, dan frekuensi rendah nilai $N$-gain $<0,3$. Data tersebut menunjukkan bahwa hasil belajar kognitif peserta didik lebih banyak dalam kategori sedang, dan belum mencapai hasil maksimal yaitu kategori tinggi. Hal tersebut dikarenakan pada saat mengerjakan pretest dan postest peserta didik tidak mengerjakan sepenuhnya dengan baik.

Keterampilan komunikasi lisan peserta didik dalam penelitian ini didapat data dari hasil self assessment, peer assessment dan lembar observasi yang dapat dilihat nilai rata-ratanya seperti yang terdapat pada gambar grafik 2. Berdasarkan penelitian yang telah dilakukan diketahui bahwa model pembelajaran kooperatif tipe Jigsaw dapat menumbuhkan keterampilan komunikasi tertulis peserta didik. Keterampilan lisan juga dinilai saat peserta mempresentasikan di hadapan temantemannya. Berikut merupakan contoh keterampilan komunikasi lisan pada soal pada gambar ekosistem padang rumput di atas jelaskan interaksi antara tumbuhan dan cahaya matahari dan jenis interaksi apakah yang terjadi antar 
komponen ekosistem tersebut? Kemudian beri contoh yang lain!

"Interaksi antara tumbuhan dan cahaya matahari yaitu tumbuhan berinteraksi dengan cahaya matahari untuk membuat makanannya sendiri melalui proses fotosintesis. Jenis interaksi tersebut adalah tumbuhan sebagai komponen biotik dan cahaya matahari sebagai komponen abiotik, jadi itu adalah salah satu bentuk interaksi antara komponen biotik dengan komponen abiotik. Contoh lain: tumbuhan dan tanah, tanah berguna bagi tumbuhan untuk tumbuh dan berkembang, tanpa adanya tanah tumbuhan tidak dapat hidup, karena kekurangan unsur hara".

Kalimat yang diucapkan peserta didik tersebut sudah jelas dan mudah dimengerti, namun pada saat presentasi indikator yang belum tercapai yaitu kurang adanya pertanyaan dari audien dan kurang dalam memberi jawaban kepada audien karena siswa hanya terfokus untuk mendengarkan penjelasan tersebut.

Berdasarkan hasil bahwa lebih dari $75 \%$ peserta didik memiliki kriteria keterampilan komunikasi lisan dengan kategori cukup. Selain itu, dapat dilihat pada (Tabel 3) berdasarkan penilaian per indikator keterampilan komunikasi tertulis peserta didik yang diambil dari penilaian self assessment dan observasi diperoleh rata-rata persentase sebesar $73 \%$ dengan kategori cukup.

Hal ini sesuai dengan kriteria keefektifan menurut Wicaksono (2008: 25) yang menyatakan bahwa model pembelajaran dikatakan efektif menumbuhkan keterampilan komunikasi peserta didik apabila sekurang-kurangnya $75 \%$ dari jumlah siswa memiliki kriteria keterampilan komunikasi cukup.

Peningkatan hasil belajar kognitif ini didukung oleh pernyataan dari Amri dan Ahmadi (2010) bahwa pembelajaran tipe Jigsaw mengajarkan siswa untuk bekerja sama dan bertanggung jawab. Pembelajaran koperatif Jigsaw merupakan suatu tipe pembelajaran kooperatif yang terdiri dari beberapa anggota dalam satu kelompok yang bertanggung jawab atas penguasaan bagian materi belajar dan mampu mengajarkan materi tersebut kepada anggota kelompok lain dalam kelompoknya.

Saat proses pembelajaran, selain harus menggunakan model pembelajaran yang tepat, pendidik juga harus membuat pengalaman belajar agar berkesan, yaitu dengan belajar melalui pengalaman langsung (learning by doing). Karena, peserta didik dapat memperoleh lebih banyak pengalaman dengan cara keterlibatan secara aktif dan proporsional dibandingkan hanya melihat materi atau konsep, sehingga akan berdampak pada meningkatnya hasil belajar. Menurut Dewey, modus pengalaman belajar adalah sebagai berikut: saya belajar $10 \%$ dari apa yang saya baca, $20 \%$ dari apa yang saya dengar, 30\% dari apa yang saya lihat, $50 \%$ dari apa yang saya lihat dan dengar, $70 \%$ dari apa yang saya katakan, dan $90 \%$ dari apa yang saya katakan dan lakukan. Hal ini ada kaitannya dengan pendapat yang dikemukakan oleh seorang filsuf cina confocius, bahwa: "apa yang saya dengar, saya lupa; apa yang saya lihat, saya ingat; dana apa yang saya lakukan saya paham". Dari uraian tersebut maka dapat disimpulkan bahwa hasil belajar akan naik karena peserta didik mengkomunikasikan dan mengatakan pengetahuan yang ia dapatkan, sehingga daya ingatnya bertahan lama, sehingga hasil belajar peserta didik dapat meningkat.

Hal ini didukung oleh Arends (2007: 5) yang menyatakan bahwa model pembelajaran Kooperatif Tipe Jigsaw dapat menumbuhkan tanggung jawab peserta didik sehingga terlibat langsung secara aktif dalam memahami suatu persoalan dan menyelesaikannya secara kelompok, dan dikuatkan oleh Ibrahim, dkk. (2000:6) yang mengungkapkan bahwa pembelajaran kooperatif dapat menumbuhkan interaksi antar peserta didik sehingga peserta didik menjadi lebih termotivasi, lebih aktif dalam proses pembelajaran dan dapat mengembangkan sikap ilmiah peserta didik, sehingga hasil belajar peserta didik pun semakin meningkat.

\section{SIMPULAN, SARAN, DAN REKOMENDASI}

Berdasarkan hasil penelitian dan pembahasan, maka dapat disimpulkan bahwa:

1. Model pembelajaran kooperatif tipe Jigsaw efektif dalam menumbuhkan keterampilan komunikasi lisan peserta didik kelas X SMA Muhammadiyah 2 Bandar Lampung diperoleh kategori cukup (akumulasi dari kategori sangat tinggi, tinggi dan cukup) dengan persentase $97 \%$. 
2. Model pembelajaran kooperatif tipe Jigsaw efektif dalam meningkatkan hasil belajar kognitif peserta didik kelas X SMA Muhammadiyah 2 Bandar Lampung diperoleh kategori sedang dengan $\mathrm{N}$-gain 0,56.

\section{DAFTAR PUSTAKA}

Amri, dan Ahmadi. (2010). Konstruksi Pengembangan Pembelajaran. Jakarta: Prestasi Pustaka, 94.

Arends, R.I.. (2007). Exploring Teaching: An Introduction to Education. Mc Graw-Hill Companies. New. York.

Arikunto, S. (2010). Prosedur Penelitian Suatu Pendekatan Praktik. Jakarta: Rineka Cipta.

Australia Curriculum Council. Curriculum Development Council Science syllabus for secondary schools: The curriculum framework for kindergarten to year 12 education in WesternAustralia.

Kemendikbud. (2008). Permendikbud Nilai Ratarata UN SMA IPA. Kementerian Pendidikan dan Kebudayaan. Jakarta.

Kulgemeyer, C. (2016). Impact of Secondary Students' Content Knowledge on Their Communication Skills in Science. International Journal of Science and Math, 16(1): pp. $89-108$.

Sugiyono. (2016). Metode Penelitian Pendidikan Kuantitatif Kualitatif. Bandung: Alfabeta.

Yoonsook, C, J. Yoo, S. W. Kim, H. Lee dan D. Zeidler. (2016). Enhancing Students Communication Skills In The Science Classroom Through Socioscientific Issues. International Journal of Science and Mathematics Education. 14: 1-27. 
Khoiriya Ulfa dkk. / Bioedusiana 4 (2) (2019) 